SKYSCRAPER 
This page intentionally left blank 


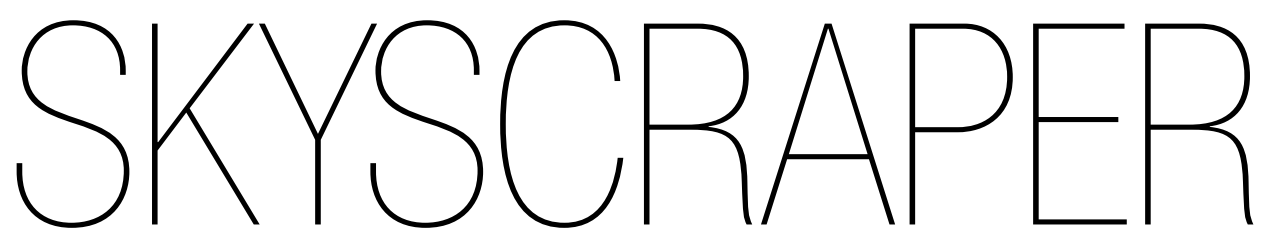

The Politics and Powern of Building New York City in the Twentieth Century

\section{BENJAMIN FLOWERS}

UNIVERSITY OF PENNSYLVANIA PRESS

PHILADELPHIA 
Copyright (C) 2009 University of Pennsylvania Press

All rights reserved. Except for brief quotations used for purposes of review or scholarly citation, none of this book may be reproduced in any form by any means without written permission from the publisher.

Published by

University of Pennsylvania Press

Philadelphia, Pennsylvania 19104-4112

Printed in the United States of America on acid-free paper

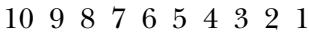

Library of Congress Cataloging-in-Publication Data

Flowers, Benjamin Sitton.

Skyscraper: the politics and power of building New York City in the twentieth century / Benjamin Flowers.

p. $\mathrm{cm}$.

Includes bibliographical references and index.

ISBN 978-0-8122-4184-6 (alk. paper)

1. Skyscrapers-New York (State)-New York. 2. Architecture and societyNew York (State)—New York-History-20th century. 3. New York (N.Y.) Buildings, structures, etc. I. Title.

NA6232.F66 2009

$720^{\prime} .483097471-\mathrm{dc} 22$ 